rooms contain souvenirs of former great Hungarian physicians. The so-called "pharmacy of Gömöry," of high artistic value, made in 1813 , is on exhibition, as well as some superb old apothecary jars from several Hungarian spas. The collection of several thousand pieces of medals, old surgical and medical instruments, and illustrations of folk medical cures must also be mentioned.
We hope that this museum, which is dedicated to the memory of the great Hungarian physician whom all the world has honoured, will attract a great number of visitors-We are, etc.,

K. FARKAS.

S. FERETE.

Swindon, Wilts. A. Palla.

power by emigration or to retain young doctors longer in the hospital service. There are no inducements to remain in hospital service apart from one's personal preference for this particulai type of medicine.

These criticisms should not detract from the motives behind the document, especially the advantages for the married houseman and the "permanent" registrar. Finally, although I criticize the B.M.A., the service given is undoubtedly good for a subsidized subscription fee of four guineas.-I am, etc., B. A. Wharton.

\title{
Hospital Junior Staff
}

SIR,-All junior hospital staff have received frequent communications (and rightly so) on the crisis in general practice-a matter which did not affect them directly. We have even had requests for financial support from the Birmingham Action Group. It is unfortunate, therefore, that the B.M.A. found it impossible to send a copy of the "Richmond Document" (a vital document to those who have chosen a hospital career) to each hospital doctor personally. The distribution to hospital secretaries, or alternatively the need for an individual request to the Association for a copy, is not satisfactory.

However, the document is very welcome and we are all indebted to the Central Consultants and Specialists Committee for its production, and particularly to Dr. HarveySmith for presenting evidence to them. The recommendations concerning residence charges, married quarters, and annual increments in pay are excellent in principle. No doubt they will be diluted considerably by the "Elephant."

Dr. Harvey Smith has asked for constructive criticisms:

Table I shows the salary one might expect on the present and proposed scale for either slow or rapid promotion up to the grade of senior registrar. The slow rate of promotion (such as seen in the major clinical specialties) shows a definite improvement in rates of pay, and indeed this was one of the aims of the proposed scales. However, even this increase is in fact $6 \%$ only. For the man enjoying a quicker promotion (e.g., as in many of the para-clinical specialties) the new rate shows no improvement- $0.5 \%$ increase only-and, in fact, for both rates of promotion the first-, second-, and third-year registrar will either have a fall in pay or no improvement. I presume this discrimination is unintentional. Nevertheless, a fall in rates of pay for our successors under whatever guise is unacceptable, and we should not accept the sop of allowing the at present first-year registrar to jump a year to $£ 1,595$ if the new scales are accepted. We have some responsibility for our successors.
Furthermore, although these scales would be subject to the 1966 pay review an excellent opportunity to point out the disparity in pay between the various branches of the profession has been missed. Table II shows the

TABLE II.-Pay Scales in the Three Clinical Branches of the N.H.S. An Efficiency Bar at (a) and a Severe Efficiency Bar at (b) are Present

\begin{tabular}{|c|c|c|c|}
\hline \multicolumn{2}{|c|}{$\begin{array}{l}\text { Hospital Service } \\
\text { Proposed Scales }\end{array}$} & \multirow{2}{*}{$\begin{array}{c}\text { General } \\
\text { Practice } \\
\text { from } \\
\text { B.M.尹. Adverts }\end{array}$} & \multirow{2}{*}{$\begin{array}{l}\text { Public Health } \\
\text { Asst. M.O. } \\
\text { Assuming } \\
\text { No Promotion }\end{array}$} \\
\hline Rapid & Slow & & \\
\hline $\begin{array}{r}1,000 \\
1,100 \\
\text { (a) } 1,425\end{array}$ & $\begin{array}{l}1,000 \\
1,100 \\
1,255\end{array}$ & $\begin{array}{l}2,000+\text { house } \\
\text { (a) } 3,000 \text { junior }\end{array}$ & $\begin{array}{l}\overline{1,515} \\
1,590\end{array}$ \\
\hline $\begin{array}{r}1,525 \\
1,595 \\
\text { (b) } 1,940 \\
2,050\end{array}$ & $\begin{array}{l}1,355 \\
1,425 \\
1,525 \\
1,595\end{array}$ & PARÍTY & $\begin{array}{l}1,665 \\
1,740 \\
1,815 \\
1,890\end{array}$ \\
\hline
\end{tabular}

rates of pay expected during the first seven years in the main branches of the N.H.S Are we, after only being less than seven years qualified, really worth only a half that of our general-practitioner colleagues of roughly the same age and experience? Or alternatively does general practice really need $100 \%$ inducement allowance-i.e., less than that offered to join the armed Forces? Salaries will to some extent depend on the labour available, but there is adequate evidence to show that the hospital service is as acutely short of young doctors as other branches of the N.H.S., especially as $40 \%$ of our members are foreign graduates.

I would conclude that:

(a) The increase for "slow promotion," although welcome, is small.

(b) Those enjoying a "rapid promotion" would have no increase and in some years would be worse off than under the present scales.

(c) First-, second-, and third-year registrars and first-year S.H.O.s would show no benefit and might well be worse off.

(d) The differential between pay scales of the hospital service and other branches of the N.H.S remain enormous without adequate professional or economic reasons for such a large difference.

(e) The changes proposed in the memorandum will do little to reduce the drain of medical man-

TABLE I.-Present and Proposed Salary Scales (in £) for Rapid or Slow Promotion

\begin{tabular}{|c|c|c|c|c|}
\hline & \multicolumn{2}{|c|}{ Slow Promotion } & \multicolumn{2}{|c|}{ Rapid Promotion } \\
\hline & Present & Proposed & Present & Proposed \\
\hline & $\begin{array}{r}810 \\
949 \\
1,195 \\
1,195 \\
1,425 \\
1,595 \\
1,595 \\
1,595\end{array}$ & $\begin{array}{l}1,000(+23 \%) \\
1,100(+17 \%) \\
1,255(+5 \%) \\
1,355(+13 \%) \\
1,425(-4 \%) \\
1,525(-4 \%) \\
1,595(-10 \%) \\
1,745(+10 \%)\end{array}$ & $\begin{array}{l}810 \\
1,195 \\
\\
1,425 \\
1,595 \\
1,595\end{array}$ & $\begin{array}{l}1,000(+23 \%) \\
1,100(-8 \%) \\
1,425 \quad- \\
1,525 \quad(-4 \%) \\
1,595\end{array}$ \\
\hline & \multicolumn{2}{|c|}{9 Years Qualified } & \multicolumn{2}{|c|}{5 Years Qualified } \\
\hline $\begin{array}{l}\text { Total income : } \\
\text { (a) including pre-reg. year } \\
\text { (b) excluding pre-reg. year }\end{array}$ & $\begin{array}{l}11,945 \\
11,130\end{array}$ & $\begin{array}{l}12,640(+6 \%) \\
11,640(+5 \%)\end{array}$ & $\begin{array}{l}6,620 \\
5,810\end{array}$ & $\begin{array}{ll}6,645 & (0.5 \%) \\
5,645 & (-3 \%)\end{array}$ \\
\hline
\end{tabular}

Sorrento Maternity Hospital,

Birmingham 15 .

SIR,-It was with interest that we read the recent memorandum "An Appraisal of the Hospital Service" (Supplement, 17 July, p. 70). Many of its proposals will be welcomed by junior hospital doctors. At a time when general-practitioner claims are very much to the fore it may be that the importance of this document will be overshadowed, and fear of this prompts us to write this letter.

A salary system based on yearly increments is highly desirable and long overdue. The scale proposed, however, is set surprisingly low. This is disappointing in a report which puts forward so many excellent principles regarding terms of service.

While those newly qualified would receive a much more reasonable salary, the rates proposed after the first two years are grossly inadequate. At one stage there would be little or no increase above the existing levels introduced in March 1963.

We can only hope that this fact will not be overlooked by those responsible for forwarding these new proposals to the review body, and that a higher scale will be substituted.-We are, etc.,

\section{J. A. Child.}

\section{Lewisham Hospital, S. GallanNaUgh. \\ London S.E.13.}

\section{Royal Commission on Medical Education}

SIR,-There can be no doubt that the setting up of a Royal Commission to survey and report on medical education will be approved by everyone. The present shortage of medical manpower is acute, and every branch of medical activity-hospitals, general practice, public health, the armed Forces, and so on-all seem to have deficiencies in their establishments, and, with increased commitments, these deficiencies look like growing rather than receding. The only branch which seems to have an adequacy of personnel (some would say too many) appears to be the teaching hospitals.

It must be said, therefore, that the constitution of the Royal Commission must give rise to some concern. Of the eminence and ability of the individual members of the Commission there cannot be the least shadow of doubt, and had the purpose of the Commission been to investigate the scientific development of medicine in this country it is doubtful whether a stronger team could have been gathered together. But, Sir, the question they are to investigate is medical 